\title{
Enhancing Students' Higher-Order Thinking Skills (HOTS) Through an Inductive Reasoning Strategy Using Geogebra
}

\author{
https://doi.org/10.3991/ijet.v15i03.9839 \\ Noor Suhaily Misrom $(\bowtie)$ \\ Universiti Teknologi Malaysia, Johor Bahru, Malaysia \\ noorsuhailymisrom@gmail.com \\ Muhammad Sani Abdurrahman \\ Waziri Umaru Federal Polytechnic Birnin Kebbi, Nigeria \\ Abdul Halim Abdullah, Sharifah Osman \\ Universiti Teknologi Malaysia, Johor Bahru, Malaysia \\ Mohd Hilmi Hamzah \\ Universiti Utara Malaysia, Changlun, Malaysia \\ Ahmad Fauzan \\ Universitas Negeri Padang, Padang, Indonesia
}

\begin{abstract}
The concept of Higher-Order Thinking Skills (HOTS) is one of the highlighted aspects in producing human capital of high quality. However, the level of HOTS among students in Malaysia is still at a lower stage. Among the causes of this problem is the learning strategy used in classroom, which is less effective in creating and enhancing HOTS optimally. Therefore, the main focus in this study was to investigate the potential role of an inductive reasoning strategy using Geogebra in increasing the students' level of HOTS. Besides, it also aimed to identify the relationship between HOTS and students' inductive reasoning for the topic of Graphs of Functions II. The design of study was quasi-experimental which involved 94 form-four students from a secondary school in Johor. The sample of this study was divided into three groups: (1) Treatment Group 1 (inductive reasoning strategy using Geogebra); Treatment Group 2 (inductive reasoning strategy); and (3) a control group (conventional). The instrument of the study comprised a set of HOTS questions and a worksheet based on an inductive reasoning strategy using Geogebra. Using the Multivariate Analysis of Variance (MANOVA), it was found that the overall HOTS level of the students, which included applying, analysing, evaluating and creating skills, could be enhanced through this strategy. The findings also show that there was a positive relationship between HOTS and inductive reasoning. In conclusion, an inductive reasoning strategy can provide positive impacts on students' HOTS in the topic of Graphs of Functions II.
\end{abstract}

Keywords-HOTS, Inductive Reasoning Strategy, Geogebra 


\section{Introduction}

Mathematics is one of the most emphasised subjects in school that complements the development of science and technology. Therefore, enhancing the knowledge of Mathematics is important in order to produce human capital that is equipped with $21^{\text {st }}$ century skills and can compete at an international level. [1] states that Mathematics involves not only mastering basic concept and skills, but also understanding thinking skills in Mathematics, applying various problem-solving skills, creating communication in Mathematics, and instilling positive values.

\subsection{Students' HOTS in Malaysia}

HOTS is a continuation of the Integrated Primary School Curriculum (KBKK) and it puts thinking skills at a higher level [2][3]. In this highly competitive era, students have to think at a higher level in receiving new information, organising and storing information in a long-term memory, making connections between new information and existing knowledge, and processing the information to solve a problem [4][3]. Many researchers have shown that the Malaysian students are yet to master the four HOTS skills highlighted in a revised Bloom Taxonomy, which are the skills of application, analysis, evaluating and creating. [5] states that the Malaysian students are facing difficulties in applying what they have learned in school into their real life. This statement is supported by [3] who has proven that the Malaysian students are having problems in integrating their existing mathematical knowledge and also in applying a suitable strategy in solving a problem. Moreover, the students are also facing problems in analysing information because of their weakness in making inferences and providing evidence to support a statement. [3] states that most students can understand the question, retrieve information and investigate the information. However, they fail to make generalisations or connections between the information, leading to a failure in making an accurate conclusion. This proves that the students' capability in solving questions that require an analysis is still at a low level.

Some studies also report that the Malaysian students' evaluating level is still low; the students are claimed to be weak in the aspect of analysis because they are accustomed to the questions in the previous examination format that only emphasises the levels of remembering, understanding, applying and analysing [6]. [3] has also proven that Malaysian students are less skilful in answering questions on Mathematics that require evaluating. Consequently, the students are having problems in the aspect of creating because both new and existing knowledge should be applied, analysed and evaluated in order to create a solution for the problem [4]. Therefore, when the students are facing difficulties in applying, analysing and evaluating a problem, indirectly, they are also having challenges in making or creating a solution. This proves that the Malaysian students' level of HOTS is still low and also below the standard underlined by the Malaysia's Ministry of Education (MOE). 


\subsection{Learning difficulties in the topic of graphs of functions II}

The topic of Graphs of Functions II is the second topic in the Malaysian form-five syllabus and is the continuation of the topic of Graphs of Functions I introduced to the Malaysian students when they are in Form Three. This topic is one of the topics under the field of relations that introduce the concepts of patterns, tips, general principles, law, relation, etc., in identifying and understanding relations between numbers and shapes [7]. According to [8], students should be first given the chance to build their mathematical concepts before being introduced to HOTS questions. This is because students are only given the chance to explain mathematical concepts verbally although they actually do not fully understand such concepts. This has hindered them from applying their knowledge in answering HOTS questions because their understanding of mathematical concepts is still at a low level [9].

This situation also applies in the current topic because several studies have shown that the students' understanding of mathematical concepts is at a low level [10] [11]. Indirectly, this leads to the students' weakness in HOTS for this topic since their understanding of mathematical concepts is needed to stimulate HOTS [12]. A few studies conducted on HOTS for this topic found that students are facing problems in the aspect of application because they are not able to visualise the concept that they have learned [10]. Visualising is one of the skills that helps in enhancing students' HOTS [12]. However, students' mental image is still limited to a smooth and persistent line/ curve and, therefore, they are not able to visualise the shape of graphs of functions [13]. This misconception has led students to only accept graphs of functions with a good shape like a circle, and reject graphs of functions with an odd shape.

It is important for students to master the concept of this topic as it requires students to make connections [14]. According to [12], one of the HOTS skills includes making connection or relations between concepts. Nevertheless, students are having problems in the aspect of analysing because they are weak in establishing relevance between the concepts of variables, domain, range and image [15] [16] [14]. [17] also state that students are having difficulties in making decisions and providing justifications for such decisions. Most students are not able to discuss further nor verify the chosen answer because they only depend on formulae and, therefore, are not able to see the effect of parameter changes in graphs [10]. This proves that students are less skilful in the aspect of evaluation.

Among the difficulties faced by students are visualising, predicting and sketching the shape of the graphs [18]. They are less skilful in predicting the shape and sketching graphs because they tend to memorise the concept rather than understanding it [16]. According to [7], making predictions is one of the characteristics of creating a skill. [4] state that, when students face problems in application, analysis and evaluation, they will also have problems in making or creating a solution since this aspect requires the highest cognitive level. This empirical evidence shows that the students' HOTS level for this topic is still at a low level. Therefore, they should be exposed to more effective learning strategies in order to improve their understanding of this topic, thus enhancing their HOTS [19] [4]. 


\subsection{The potential role of an inductive reasoning strategy in HOTS}

An inductive reasoning strategy is one of the potential learning strategies that can be used to introduce students to basic concepts in obtaining clear visualisations while stimulating their HOTS [12]. According to [20], reasoning processes like inductive reasoning can stimulate HOTS since the processes included in this strategy apply HOTS skills which are applying, analysing, evaluating, and creating. Through this strategy, students are able to use the highest cognitive level to stimulate HOTS. As stated in [21], among the characteristics of HOTS are pattern discovery, complex application, interpreting information, solving problems in mathematical sentences, and understanding concepts. This is in line with inductive reasoning that is suitable in learning concepts that put greater emphasis on discovering patterns, interpreting information to make generalisations, and making analyses by finding similarities, differences and relations between the attributes [22]. Thus, this strategy has the potential to stimulate HOTS since there is a relationship between HOTS and an inductive reasoning strategy in the aspects of applying, analysing, evaluating and creating.

An inductive reasoning strategy is related to HOTS in the aspect of applying because this strategy requires students to build understanding based on their observations of specific examples. Based on this understanding, they will be able to master basic concepts and apply them in a new situation [23] [24]. Students will face problems in applying knowledge if the basic concepts are not fully mastered and the built understanding could not be used to solve a mathematical problem in a new situation. Moreover, this strategy can enhance students' analysing skills because they have to compare patterns and identify the relationship based on their observation before making a generalisation. According to [25], inductive reasoning requires students to analyse given examples by investigating information according to components and making connections between these components. This process is highly potential in improving students' analysing skills, thus enhancing their HOTS.

An inductive reasoning strategy also has the potential to improve evaluating skills because students have to provide a justification for a generalisation made based on their observation. In this context, students not only state a generalisation but also verify the reasons for such a generalisation [26]. This process stimulates students' evaluating skills as they have to put forward considerations and provide justifications for their decisions. In conclusion, an inductive reasoning strategy has the potential to stimulate student's creating skills because they have to make predictions and build their own understanding based on their observation. According to [23], students have to integrate the information retrieved based on their observation in order to create a conclusion. This process is related to the aspect of creating, which proves that, when students are exposed to inductive reasoning, their HOTS will be indirectly stimulated.

\subsection{The potential role of Geogebra in HOTS}

The 21st century learning, other than implementing HOTS in Mathematics, needs an educational resource aid based on technology, such as Geogebra, the dynamic geometrical software. The learning strategy using technology has been claimed to help students 
in mastering a two-way learning without fully depending on a teacher. Through Geogebra, students can learn actively, independently and flexibly through exploration, problem-solving and reasoning [27] [28]. Moreover, it can make mathematical concepts more interesting and understandable through visualisation because there are interesting and colourful texts and graphics in Geogebra. Geogebra is dynamic mathematics software and is suitable to be used at all educational levels. This software is different compared to most mathematics software as they are more focused on geometry. Uniquely, this software is interactive and user-friendly. It also focuses on geometry, algebra and calculus [29] [30]. According to [31], Geogebra can make points, lines, graphs, polygons, translation and other functions more easily and accurately. The characteristics of Geogebra ease students in starting a construction activity from easy to complex ones, and also in investigating the constructions.

The use of Geogebra has improved students' HOTS because, according to [32], students are encouraged to think critically and creatively while exploring. This helps students to make assumptions, predictions and hypotheses. Besides, students can also clearly relate their existing knowledge to the new one through visualisation. [33] state that learning using Geogebra can increase students' mental processes towards a higher lever and give students the chance to build, explore and observe geometrical characteristics. Geogebra also has the potential to enhance students' understanding of concepts [34] [32] [35] [36]. Geogebra gives clear information by providing images and graphics which are helpful to aid students in understanding a particular concept. This leads students to enhance their HOTS after mastering the basic concept of a topic. Since there are many advantages of inductive reasoning and Geogebra, this research was carried out to identify students' HOTS as a whole in the aspect of applying, analysing, evaluating and creating. It also examined the relationship between students' HOTS and an inductive reasoning strategy after using Geogebra.

\section{Methodology}

This research used a quantitative and quasi-experimental approach. A quasi-experimental approach with the non-equivalent group's pre-post-test design was used to test the efficacy of a programme when research samples were not distributed randomly [37]. To fulfil the research objectives, three Form-Four classes in one of the schools in Johor comprising 94 students were chosen as the research samples. The samples were divided into three groups:

- Treatment Group 1 (learning through an inductive reasoning strategy using Geogebra)

- Treatment Group 2 (learning through an inductive reasoning strategy)

- A control group (conventional learning).

The sample of activities are shown in Appendix 1. HOTS Test Set for Graphs of Functions II was used to answer the first research objective. The pre- and post-tests on HOTS were used to study the efficacy of the learning strategy towards HOTS in the 
aspect of applying, analysing, evaluating and creating. The HOTS questions are as shown in the Table 1.

Table 1. HOTS Questions

\begin{tabular}{|l|l|}
\hline $\begin{array}{l}\text { Applying } \\
\text { Question }\end{array}$ & $\begin{array}{l}\text { A tennis ball is thrown into the air from the edge of a } 20 \text { feet tower with an initial speed of } \\
15 \text { feet per second. The diagram below illustrates the sketch of the graph for the movement of } \\
\text { the tennis ball when it was thrown. The height of the tennis ball } t \text { seconcs after being thrown } \\
\text { is given by the quadratic equation } \mathrm{h}=-5 \mathrm{t}^{2}+15 \mathrm{t}+\mathrm{q} \text { where } h \text { is the height in feet. }\end{array}$ \\
i. \\
Based on the above statement, complete the equation for the height $\mathrm{h}$ of the ball \\
$\mathrm{h}=-5 \mathrm{t}^{2}+15 \mathrm{t}+\mathrm{q}$ after $t$ seconds. \\
What is the height of the tennis ball at the $2^{\text {nd }}$ time? \\
How long does it take for the tennis ball to hit the ground? Show your calculations and \\
justify the choice of the answer.
\end{tabular}




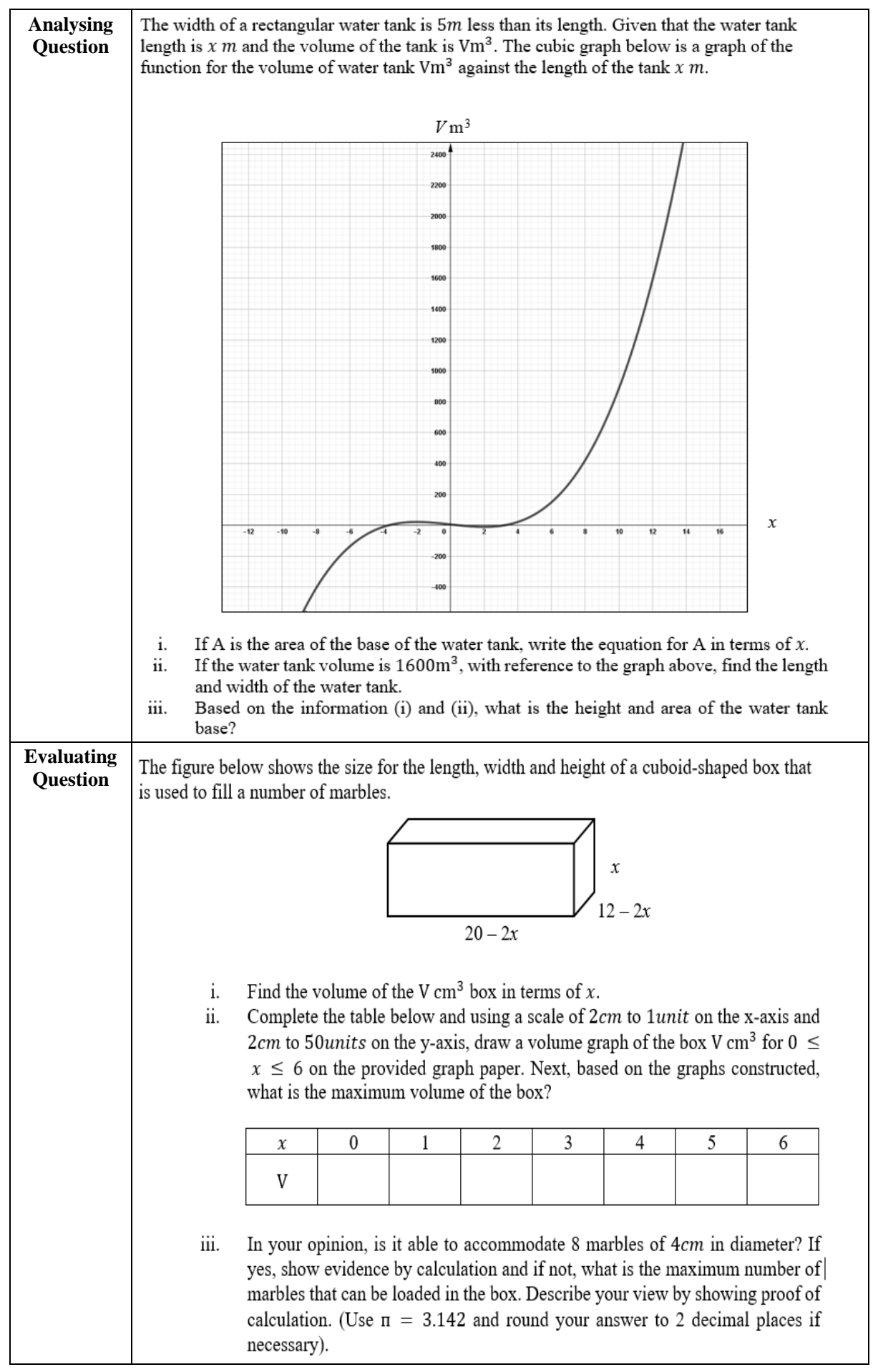




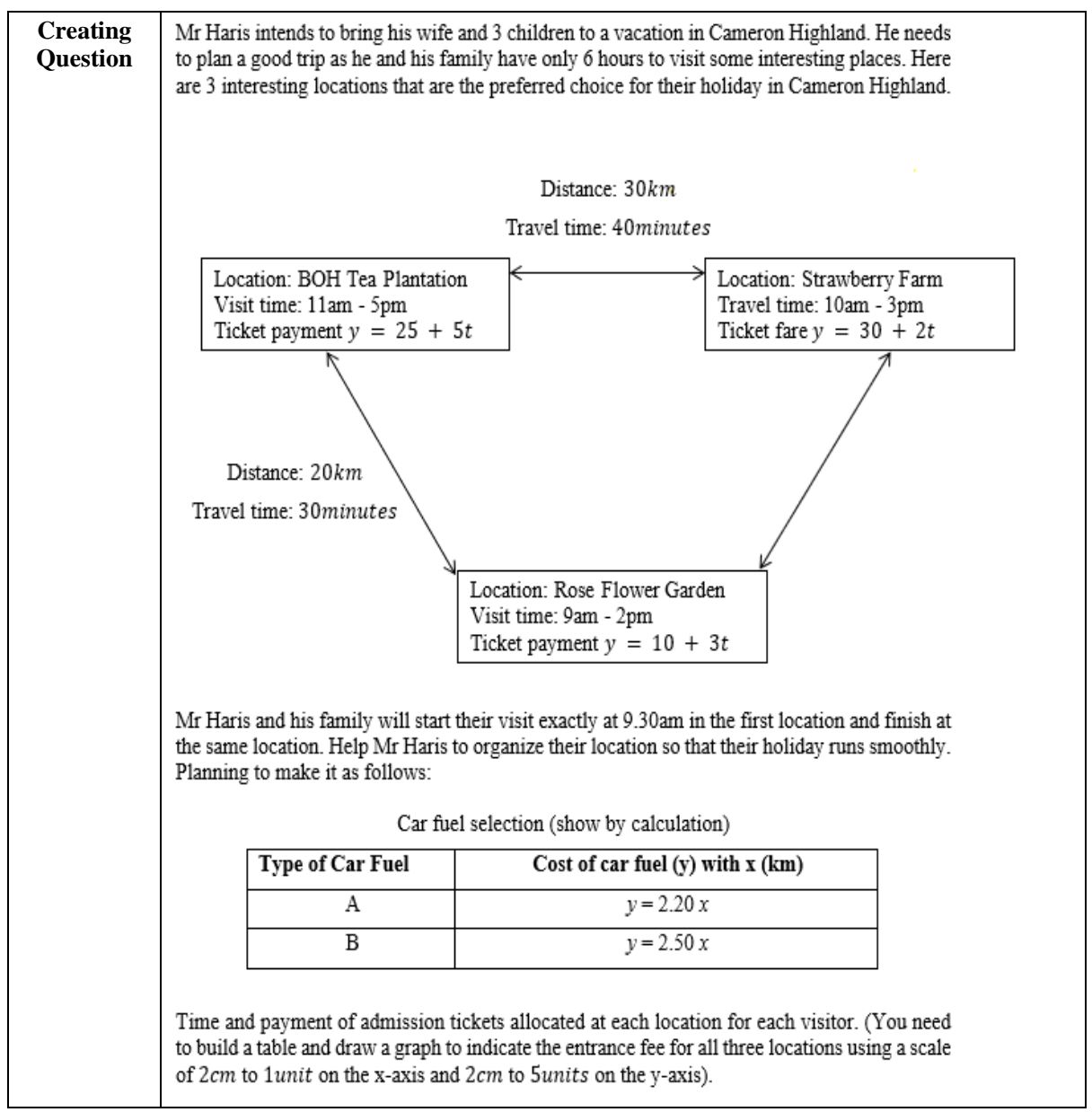

This test was self-constructed by the researcher based on the concept of Graphs of Functions II. The students' answers were checked using a scoring rubric constructed based on the Score Specification Table proposed by [38]. Validity tests for the content of the HOTS test and the scoring rubric were carried out by three experts chosen based on their expertise and qualification in the field of Mathematics. Improvements were made based on the comments and suggestions given by the experts. Seven sets of worksheet were used to introduce an inductive reasoning strategy to Treatment Group 1 and Treatment Group 2. These sets were constructed based on the inductive reasoning steps proposed by [39]. Emphasis was given on the concept of graphs and the effect of constant and parameter on four types of graphs of functions, which are linear, quadratic, cubic and reciprocal graphs. According to [12], students have to be exposed to building concepts and making connections between concepts in order to get a wider view that helps stimulate their HOTS. The types of tasks designed in these sets were finding the differences or similarities among attributes (characteristics) and identifying the relationship. As stated by [22], this kind of task can be used to stimulate HOTS. A four- 
point scoring rubric was also constructed based on the Score Specification Table by [38]. The rubric was used so that the researcher could check the students' work accurately and fairly based on the indicators for each score. Content validity for the worksheet and the scoring rubric was done by three Mathematics content experts. Improvements were made based on the suggestions given by the experts before being distributed to the actual groups. Data retrieved from the HOTS test was ratio data that involves a scoring rubric. Therefore, the researcher used the Multivariate Analysis of Variance Test (MANOVA) to analyse the HOTS data. This particular analysis can study the effect of an independent variable on more multiple dependent variables in a particular data set [37]. The researcher used the Pearson correlation test (r) to study the relationship between inductive reasoning and the students' HOTS. The comparison of coefficient values was made between Treatment Group 1 and Treatment Group 2 in order to identify the level of relationship between inductive reasoning and HOTS in each group.

\section{$3 \quad$ Research Finding}

\subsection{Finding on HOTS differences between groups}

For this study, the MANOVA analysis was used to see whether there were significant differences between Treatment Group 1, Treatment Group 2 and a control group on the four HOTS aspects (applying, analysing, evaluating, creating). The Pillai's Trace value was used as a reference in the MANOVA analysis because the value is thorough and suitable to be used for groups with different numbers of respondents [40]. Then, the data analysis was carried out separately (Test of Between-Subjects Effect) for the four HOTS aspects. An analysis using Bonferroni alpha value of $(0.05 / 4)=0.0125$ was carried out because the researcher wanted to get an accurate result. This Bonferroni alpha value was the result of the original significant value divided by the number of dependent variables used. The use of Bonferroni alpha value controls Type 1 Error that is common in research [41] [40]. Table 2 below shows descriptive statistical results for HOTS and all four aspects of HOTS for all three groups. 
Table 2. Post-test descriptive statistics

\begin{tabular}{|c|c|c|c|c|}
\hline Subject & Group & Mean & Std. deviation & $\mathbf{N}$ \\
\hline \multirow[t]{4}{*}{ Post overall } & Treatment Group 1 & 11.63 & 2.379 & 32 \\
\hline & Treatment Group 2 & 10.58 & 2.460 & 31 \\
\hline & Control group & 8.74 & 2.944 & 31 \\
\hline & Total & 10.33 & 2.841 & 94 \\
\hline \multirow[t]{4}{*}{ Post applying } & Treatment Group 1 & 3.25 & .950 & 32 \\
\hline & Treatment Group 2 & 2.87 & .763 & 31 \\
\hline & Control group & 2.23 & 1.023 & 31 \\
\hline & Total & 2.79 & 1.004 & 94 \\
\hline \multirow[t]{4}{*}{ Post analysing } & Treatment Group 1 & 3.28 & 1.023 & 32 \\
\hline & Treatment Group 2 & 3.13 & .991 & 31 \\
\hline & Control group & 2.55 & 1.261 & 31 \\
\hline & Total & 2.99 & 1.131 & 94 \\
\hline \multirow[t]{4}{*}{ Post evaluating } & Treatment Group 1 & 2.50 & .672 & 32 \\
\hline & Treatment Group 2 & 2.65 & .985 & 31 \\
\hline & Control group & 1.81 & .792 & 31 \\
\hline & Total & 2.32 & .895 & 94 \\
\hline \multirow[t]{4}{*}{ Post creating } & Treatment Group 1 & 2.59 & .911 & 32 \\
\hline & Treatment Group 2 & 1.94 & .727 & 31 \\
\hline & Control group & 2.16 & .735 & 31 \\
\hline & Total & 2.23 & .835 & 94 \\
\hline
\end{tabular}

Table 1 shows that the overall post HOTS mean value for Treatment Group 1 overtops the mean values for other groups (overall post HOTS mean: Treatment Group $1=$ 11.63, Treatment Group $2=10.58$, and Control Group $=8.74$ ). This analysis also shows that the mean value for applying, analysing and creating skills for Treatment Group 1 overtops the other groups (post-applying mean: Treatment Group $1=3.25$, Treatment Group $2=2.87$ and Control Group $=2.23$, post-analysing mean: Treatment Group $1=$ 3.28 , Treatment Group $2=3.13$ and Control Group $=2.55$, post-creating mean: Treatment Group $1=2.59$, Control Group $=2.16$ and Treatment Group $2=1.94$ ). Nonetheless, the mean value for evaluating skills for Treatment Group 2 overtops the other groups (post-evaluating mean: Treatment Group $2=2.65$, Treatment Group $1=2.50$ and Control Group = 1.81).

Table 3. Multivariate test for HOTS test

\begin{tabular}{|l|l|c|c|c|c|c|}
\hline \multicolumn{2}{|l|}{ Effect } & Value & F & Hypothesis df & Error df & Sig. \\
\hline \multirow{4}{*}{ Intercept } & Pillai's Trace & .944 & $369.179^{\mathrm{b}}$ & 4.000 & 88.000 & .000 \\
\cline { 2 - 7 } & Wilks' Lambda & .056 & $369.179^{\mathrm{b}}$ & 4.000 & 88.000 & .000 \\
\cline { 2 - 7 } & Hotelling's Trace & 16.781 & $369.179^{\mathrm{b}}$ & 4.000 & 88.000 & .000 \\
\cline { 2 - 7 } & Roy's Largest Root & 16.781 & $369.179^{\mathrm{b}}$ & 4.000 & 88.000 & .000 \\
\hline \multirow{5}{*}{ Group } & Pillai's Trace & .401 & 5.572 & 8.000 & 178.000 & .000 \\
\cline { 2 - 7 } & Wilks' Lambda & .638 & $5.535^{\mathrm{b}}$ & 8.000 & 176.000 & .000 \\
\cline { 2 - 7 } & Hotelling's Trace & .506 & 5.498 & 8.000 & 174.000 & .000 \\
\cline { 2 - 7 } & Roy's Largest Root & .307 & $6.828^{\mathrm{c}}$ & 4.000 & 89.000 & .000 \\
\hline
\end{tabular}

a. Design intercept + group b. Exact statistic

c. The statistic is an upper bound on $\mathrm{F}$ that yields a lower bound on the significance level 
Table 3 illustrates the multivariate tests analysis which shows that there is a significant effect of independent variables for significant group $[\mathrm{F}(8,178)=5.572, \mathrm{p}<0.05]$ on the four dependent variables overall.

Table 4. Tests between subjects effects for HOTS

\begin{tabular}{|c|c|c|c|c|c|c|}
\hline Source & Dependent Variable & $\begin{array}{c}\text { Type III Sum } \\
\text { of Squares }\end{array}$ & df & Mean Square & $\mathbf{F}$ & Sig. \\
\hline \multirow{4}{*}{ Corrected Model } & Post_applying & $16.841^{\mathrm{a}}$ & 2 & 8.421 & 9.964 & .000 \\
\hline & Post_analysing & $9.359^{b}$ & 2 & 4.680 & 3.884 & .024 \\
\hline & Post_evaluating & $12.490^{\mathrm{c}}$ & 2 & 6.245 & 9.176 & .000 \\
\hline & Post_creating & $7.068^{\mathrm{d}}$ & 2 & 3.534 & 5.565 & .005 \\
\hline \multirow{4}{*}{ Intercept } & Post_applying & 727.487 & 1 & 727.487 & 860.840 & .000 \\
\hline & Post_analysing & 838.060 & 1 & 838.060 & 695.644 & .000 \\
\hline & Post_evaluating & 504.614 & 1 & 504.614 & 741.415 & .000 \\
\hline & Post_creating & 467.421 & 1 & 467.421 & 736.118 & .000 \\
\hline \multirow{4}{*}{ Group } & Post_applying & 16.841 & 2 & 8.421 & 9.964 & .000 \\
\hline & Post_analysing & 9.359 & 2 & 4.680 & 3.884 & .024 \\
\hline & Post_evaluating & 12.490 & 2 & 6.245 & 9.176 & .000 \\
\hline & Post_creating & 7.068 & 2 & 3.534 & 5.565 & .005 \\
\hline \multirow{4}{*}{ Error } & Post_applying & 76.903 & 91 & .845 & & \\
\hline & Post_analysing & 109.630 & 91 & 1.205 & & \\
\hline & Post_evaluating & 61.935 & 91 & .681 & & \\
\hline & Post_creating & 57.783 & 91 & .635 & & \\
\hline \multirow{4}{*}{ Total } & Post_applying & 824.000 & 94 & & & \\
\hline & Post_analysing & 959.000 & 94 & & & \\
\hline & Post_evaluating & 580.000 & 94 & & & \\
\hline & Post_creating & 534.000 & 94 & & & \\
\hline \multirow{4}{*}{ Corrected Total } & Post_applying & 93.745 & 93 & & & \\
\hline & Post_analysing & 118.989 & 93 & & & \\
\hline & Post_evaluating & 74.426 & 93 & & & \\
\hline & Post_creating & 64.851 & 93 & & & \\
\hline
\end{tabular}

a. $\mathrm{R}$ Squared $=.180($ Adjusted $\mathrm{R}$ Squared $=.162)$

b. R Squared $=.079$ (Adjusted R Squared $=.058)$

c. $\mathrm{R}$ Squared $=.168$ (Adjusted R Squared $=.150)$

d. R Squared $=.109($ Adjusted R Squared $=.089)$

The results of the Multivariate Tests show that, overall, there is a major effect of GROUP on the four dependent variables. However, a separate analysis on dependent variables found that three out of four aspects have significant differences based on the level of Bonferroni alpha $(0.05 / 4=0.0125)$. The MANOVA result in Table 4 shows that there are significant major effects on group on three dependent variables in this study, which are applying, evaluating and creating. The results show that, significantly, group is the factor of three HOTS aspects which are applying, $[\mathrm{F}(2,91)=9.96, \mathrm{p}<$ $0.0125]$, evaluating $[\mathrm{F}(2,91)=6.25, \mathrm{p}<0.0125]$ and creating $[\mathrm{F}(2,91)=3.53, \mathrm{p}<$ $0.0125]$. This shows that group is the significant factor of applying, evaluating and creating based on the Bonferroni alpha level. In other words, the learning strategy used by all groups affects the ability of the students' HOTS in the aspects of applying, evaluating and creating. The $\mathrm{R}^{2}$ value below the table shows that group only contributes up to 
0.18 or $18 \%$ of changes in the post-applying dependent variable, 0.079 or $7.9 \%$ of changes in the post-analysing variable, 0.168 or $16.8 \%$ of changes in the post-evaluating dependent variable, and 0.109 or $10.9 \%$ of changes in the post-creating dependent variable.

\subsection{Findings on the relationship between HOTS and inductive reasoning}

Treatment group 1: To test this hypothesis, the researcher used the data from the post HOTS test and the worksheet based on the inductive reasoning strategy using Geogebra. This was conducted to see if there was a relationship between the two. The Pearson correlation test $r$ analysis was used to study the relationship between these two variables.

Table 5. Treatment group 1 correlation test

\begin{tabular}{|l|l|c|c|}
\hline \multicolumn{1}{|c|}{ Subject } & & Post & Worksheet \\
\hline \multirow{3}{*}{ Post HOTS } & Pearson Correlation & 1 & $0.317^{*}$ \\
\cline { 2 - 4 } & Sig. (2-tailed) & & 0.077 \\
\cline { 2 - 4 } & $\mathrm{N}$ & 32 & 32 \\
\hline \multirow{2}{*}{$\begin{array}{l}\text { Inductive Reasoning Work- } \\
\text { sheet }\end{array}$} & Pearson Correlation & $0.317^{*}$ & 1 \\
\cline { 2 - 4 } & Sig. (2-tailed) & 0.077 & 32 \\
\cline { 2 - 4 } & $\mathrm{N}$ & 32 & \\
\hline
\end{tabular}

Based on the result of the Pearson correlation test, the correlation coefficient is $r=$ 0.32 and it is a positive correlation although the relationship is weak [37] [42]. This finding shows that there is a relationship between the students' HOTS and an inductive reasoning strategy in solving mathematical problems after going through learning through the inductive reasoning strategy using Geogebra. However, the value of $r=$ 0.32 does not show a strong relationship up to $32 \%$ between the two variables. To confirm the contribution of inductive reasoning towards the students' HOTS, the variance value of $r^{2}$ was used. In this study, the value of $r=0.32$, so the variance value of $r^{2}=$ 0.1024 . This value shows that only $10.24 \%$ of the HOTS levels are due to the inductive reasoning learning strategy using Geogebra. The rest $89.76 \%$ is due to other factors which could not be detected.

Treatment group 2: The Pearson correlation test $r$ used to identify the relationship between HOTS and inductive reasoning shows coefficient correlation $r=0.30$ and it is a positive correlation although it has a weak relation [37] [42]. The finding shows that there is a relationship between the students' HOTS and inductive reasoning in solving mathematical problems through an inductive reasoning strategy. 
Table 5. Treatment group 2 correlation test

\begin{tabular}{|l|l|c|c|}
\hline \multicolumn{1}{|c|}{ Subject } & & Post & Worksheet \\
\hline Post group 2 & Pearson Correlation & 1 & $0.298^{*}$ \\
\cline { 2 - 4 } & Sig. (2-tailed) & & 0.104 \\
\cline { 2 - 4 } & $\mathrm{N}$ & 31 & 31 \\
\hline \multirow{3}{*}{ Worksheet 2 } & Pearson Correlation & $0.298^{*}$ & 1 \\
\cline { 2 - 4 } & Sig. (2-tailed) & 0.104 & 31 \\
\cline { 2 - 4 } & $\mathrm{N}$ & 31 & \\
\hline
\end{tabular}

Nevertheless, the value of $r=0.30$ does not show a relationship of up to $30 \%$ between the two variables. To confirm the contribution of inductive reasoning towards the students' HOTS level, the variance value $r^{2}$ was used. In this study, the value of $r=0.30$, thus the variance value $r^{2}=0.089$. This variance value indicates that only $8.9 \%$ of the HOTS level is due to an inductive reasoning learning strategy using Geogebra. The rest $91.1 \%$ is due to other unknown factors.

\section{Discussions}

\subsection{Overall students' HOTS}

Based on the findings of MANOVA, it was found that the factor of learning strategy has a significant effect on the students' HOTS. The finding shows that, overall, the HOTS level for Treatment Group 1 was higher than that of other groups. This finding proves that learning through an inductive reasoning strategy using Geogebra can enhance the students' HOTS level thoroughly. This is because Treatment Group 1 has an advantage in terms of the application of Geogebra in learning. Through Geogebra, it was found that this software can stimulate cognitive skills, increase the understanding of concept, and also enhance HOTS because students are given the chance to build their own understanding and explore more than what has been specified by the teacher. This statement is supported by [33] who assert that the use of Geogebra, if used well, can enhance the HOTS level as students can explore clearly through the visualisations provided by Geogebra.

Besides, an inductive reasoning strategy using a worksheet can also increase the students' HOTS level. This can be proven when the mean scores for post HOTS test for Treatment Groups 1 and 2 are higher than the mean of the control group. The inductive reasoning strategy is proven to stimulate HOTS because the students are actively involved in making generalisations on the basic concept of graphs based on the observation and analysis of the provided examples in the worksheet. This is in line with a statement by [21] who claim that, when students build their understanding of concept through the discovery of patterns, they are stimulating HOTS themselves. Hence, overall, this strategy can improve the understanding of concept and train students to use the highest level of their cognition. Therefore, it indirectly enhances the students' HOTS [20] [33] [43] [44]. 


\subsection{The effect of students' HOTS on the applying skill}

Based on the result of a separate MANOVA analysis on dependent variables, it was found that the learning strategy factor has a significant difference in the applying skill. Findings show that the mean score for the applying skill of Treatment Group 1 is the highest as compared to other groups. This is because, after learning through an inductive reasoning strategy using Geogebra, students are able to understand the basic concepts of Graphs of Functions II and they can apply this knowledge in a different situation. Learning through the use of a worksheet which applies an inductive reasoning strategy was found to be able to stimulate the students' capability in the applying skill. According to [44] [20] [45], this strategy helps students to get actively involved in making observations, finding patterns and making conclusions based on the information retrieved. Students can also visualise the shape of graphs in a better way. Although the worksheet provided focuses on learning the concept of graphs, it decreases the students' misconception towards the graphs shape. According to [21] [23] [12], the learning of concepts is vital in promoting HOTS especially in the aspects of applying because, when students can master the concept well, they can use the knowledge to visualise graphs and solve questions in a different situation. Therefore, the mean scores of the applying skill for Treatment Group 1 and 2 are higher than that of the control group.

Furthermore, the mean score of the applying skill for Treatment Group 1 is higher than that of other groups because the Geogebra software used in learning helps a great deal in making observations and finding patterns based on the visuals created. This finding is in line with previous studies that has shown that visualisation can enhance the understanding of concepts and improve the application skill [34] [32] [35] [36]. This shows that Geogebra can help students to improve their understanding of concepts and apply their understanding in different situations.

\subsection{The effect of students' HOTS on the analysing skill}

The results of MANOVA on dependent variables found that the learning strategy factor does not have a significant difference in the analysing skill. However, a comparison of mean scores between pre- and post-HOTS test indicate that Treatment Group 1 shows a higher improvement since they can investigate the information retrieved using the stimulus more accurately and synthesise the information to answer new questions. For Treatment Groups 1 and 2, there is a high increase in their mean scores as compared to that of the control group. This is because the inductive reasoning strategy has trained them to conduct an investigation. The worksheet used has also trained the students to find similarities, differences and relations between graphs of functions. The investigation helps them make comparisons or differentiate changes in graphs of functions when a variable is manipulated. As a result, students are able to understand the relations of graphs of functions and the effect of constant on them [14] [25]. [12] states that, by establishing relations between the variables (as also practised in exercises), students can get a clear visualisation that helps them to analyse better. This finding proves that an inductive reasoning strategy can stimulate the students' analysing skill. The use of Geogebra also helps improve the students' analysing skill as they can vividly see the 
changes in the graphs' shape visually which in turn helps them make relations between changes in graphs and the constant [46] [47]. With the help of Geogebra, students can conduct activities such as categorising graphs, finding differences and similarities between graphs, and characterising graphs. These inductive reasoning strategy activities can help students to train themselves to stimulate their own analysing skill [25].

\subsection{The effect of students' HOTS on the evaluating skill}

The result from a separate MANOVA analysis on dependent variables has also found that the learning strategy factor has a significant difference in the evaluating skill. The finding shows that the evaluating skill mean score for Treatment Group 2 is higher than that of other groups. This is because the students have gone through an inductive reasoning strategy in the worksheet. This strategy has trained them to fully focus in observing several examples given in order to find patterns and consequently make conclusions. The focus given has stimulated the students' cognitive skill in order to provide justifications and reasons for their decisions [48]. All these strategies help improve the students' evaluating skill. The finding from the evaluating skill shows that the mean score for Treatment Group 1 is lower than that for Treatment Group 2. This is potentially due to the use of Geogebra that has helped them focus on handling the software rather than on making judgement and justifications for their answers. [49] state that not all students are able to adapt themselves to Geogebra because some of them do not have basic knowledge and experience in programming. The students who have face this problem have indirectly paid less attention and made less effort in evaluating and making justifications to affirm their decisions. This situation has caused the mean score for Treatment Group 1 to be lower than that of Treatment Group 2. On the other hand, the control group is less skilful in evaluating because they are not pushed to think up to the evaluating level since they only depend on the information delivered by their teacher and the graph sketching on the graph paper. Because of that, the students in the control group are able to make the correct decision. However, they are unable to provide the reasons and justifications for their decision.

\subsection{The effect of HOTS on the creating skill}

An analysis from a separate MANOVA test on dependent variables found that the learning strategy factor has a significant difference in the creating skill. The finding shows that the mean score for Treatment Group 1 is higher than that of other groups. Since Treatment Group 1 has experienced learning through an inductive reasoning strategy using Geogebra, their score is higher than that of other groups. Inductive reasoning has potentially stimulated their cognitive level into the highest level, which is creating. Throughout the learning activity using a worksheet, the students are trained to make generalisations after observing and finding patterns and relations through the examples of graphs provided. This exercise helps students make prediction and stimulate HOTS in the aspect of creating. As a result, students are able to answer questions and handle the creating aspect better than the students in the control group [50] [51]. The Geogebra software also helps make learning more effective as it encourages the students to create 
their own creation through the adaptation of the interface provided [52]. The use of Geogebra has proven to stimulate students' HOTS including the creating skill [53] [54]. When students are regularly exposed to the environment that encourages them to create and predict the graphs' location when the variables are manipulated, their cognitive level is indirectly stimulated at the maximum level and this enhances their HOTS. Although the mean score for the creating skill of the control group is higher than that of Treatment Group 2, it was found that, based on the difference of the mean score for the pre- and post-test, the increase of score for Treatment Group 2 is higher than that of the control group. This finding proves that an inductive reasoning strategy can promote and enhance HOTS including the creating skill. When students are exposed to the skills of finding patterns and making observations in finding relations, this will lead them to make predictions and build solutions for problems [55].

\subsection{The relationship between HOTS and inductive reasoning}

The findings show that there is a positive but weak relationship between HOTS and inductive reasoning for Treatment Group 1. The findings also show a positive yet weak relationship between HOTS and inductive reasoning for Treatment Group 2, but the correlation value is weaker than that of Treatment Group 1 . There is only a $10 \%$ difference of the Pearson coefficient correlation value between the two groups. Although the relationship between the two is positive, the correlation is generally weak; the students have yet to master inductive reasoning given that the strategy is rarely practised in the classroom. According to [56], students nowadays are not exposed to learning strategies that require them to build their own understanding. This is a challenge for the teachers to vary students' learning strategies, including inductive reasoning, so that the students' HOTS can be improved. The current study has observed that the students' HOTS can be enhanced during the learning process through an inductive reasoning strategy using Geogebra. However, the students' inductive reasoning skill is still at a low level because they are less skilful in reasoning.

Besides, the weak relationship between the students' HOTS and inductive reasoning is due to the learning style through a worksheet that puts greater emphasis on learning a concept rather than solving a problem. This has hindered students from training themselves to use inductive reasoning in solving HOTS problems. Students are only trained to promote HOTS without solving HOTS problems. According to [57] [58], HOTS has a strong relationship with problem-solving; HOTS can be promoted if students are exposed to non-routine and open problems. This factor has caused a weak relationship between students' HOTS and inductive reasoning.

The $10 \%$ difference for the Pearson coefficient correlation value between Treatment Groups 1 and 2 proves that learning using Geogebra can enhance the relationship between HOTS and inductive reasoning. This is because Geogebra provides an environment that allows students to visualise clearly. Besides, students can also observe easily and clearly, find patterns based on several examples, and make generalisations. Indirectly, this helps enhance students' HOTS and their inductive reasoning skills. Learning using Geogebra is claimed to be effective in enhancing students' understanding because it functions well in the process of visualisation that provides 
students the chance to observe and discover [31] [30] [59]. [43] [46] agree that instilling HOTS in Mathematics should be supported with technology-based educational resources, such as Geogebra. This is because most students find it difficult to understand concepts, make reasoning and solve problems because of their low visualisation capability to illustrate relations between the changes in the graphs shape and the changes in the variable value [46]. With the help of Geogebra, students can visualise and imagine clearly, and further enhance their understanding of mathematical concepts.

\section{Conclusion}

Based on the findings of this study, it can be concluded that students' HOTS can be enhanced through inductive reasoning using Geogebra. The findings show that the learning of concepts through an inductive reasoning strategy using Geogebra can stimulate and improve students' HOTS. It was also found that there is a positive relationship between HOTS and inductive reasoning after the students have experienced learning through this strategy. Although the relationship is weak, it can still be enhanced if improvements are made. The research findings show that learning through an inductive reasoning strategy and technology, such as the Geogebra software, can benefit all students regardless of their age and education level [60]. This is because the strategy can stimulate HOTS, gauge interest and encourage students to explore Mathematics. Past studies have shown that some topics in Mathematics are difficult for students to understand because the concept is too abstract, which includes the topic of Graphs of Functions II [61]. Nevertheless, this can be solved by implementing an inductive reasoning strategy using Geogebra in classroom since this strategy is suitable for the learning of concepts. Moreover, the use of Geogebra further provides a visualisation technique. An inductive reasoning strategy is very useful for students to improve their understanding on the concept of Graphs of Functions II because this strategy can be implemented in the classroom to enhance students' HOTS. This strategy can stimulate students' cognitive level to a higher level and help them explore and make generalisations based on the observations of several examples provided. Consequently, this strategy improves students' understanding and helps them make conclusions on a particular relationship [25] [26]. Moreover, Geogebra can help students explore the relation between the variables and the shape of graphs. When students can visually see the relations on their own, it can enhance their learning of concepts and promote thinking at a higher level [60].

\section{$6 \quad$ References}

[1] Jamuanak, G. (2013). Integrasi permainan tradisional batu seremban dalam pedagogi matematik bagi tajuk operasi asas dalam kalangan pelajar PISMP. Jurnal Penyelidikan Tindakan.

[2] Nur, L. Z. A., Abdullah, A. H., Noor, D. A. H., Nor, H. I., Mahani, M., Johari, S., \& Norasykin, M. Z. (2017). Thinking blocks: Solving fraction problems involving higher order thinking skills. Man in India, 97(17), 121-132. 
[3] Siti-Marlina, S. (2013). Kemahiran berfikir aras tinggi (Kbat) pelajar tingkatan 5 dalam penyelesaian masalah matematik. Universiti Teknologi Malaysia.

[4] Yee, M. H., Jailani, M. Y., Widad, O., Razali, H., \& Tee, T. K. (2010). Penggunaan kemahiran berfikir aras tinggi marzano dalam penjanaan idea. Seminar majlis dekan Pendidikan IPTA, 1-10. http://doi.org/10.1007/s13398-014-0173-7.2

[5] Rajendran, N. (2008). Teaching and acquiring higher-order thinking skills: Theory \& Practice. Malaysia: Universiti Pendidikan Sultan Idris.

[6] Muhammad, Y., \& Fatimah, Z. (2011). Analisis item soalan matematik Sijil Pelajaran Malaysia Tahun 2003, 2004, 2005 dan 2006 mengikut domain kognitif Taksonomi Bloom. Journal of Science \& Mathematics Education, 2, 39-50.

[7] KPM. (2014). Elemen KBAT dalam kurikulum. Kementerian Pendidikan Malaysia. http:// doi.org/10.1017/CBO9781107415324.004

[8] Effandi, Z., Norhidayah, A., Siti, M., \& Maat, N. M. N. (2016). Teaching concept and use high order cognitive strategies in mathematics among secondary school teachers.

[9] Collins, R. (2014). Skills for the $21^{\text {st }}$ century: Teaching higher-order thinking. Curriculum \& Leadership Journal 12.

[10] Orhun, N. (2012). Graphical understanding in mathematics education: Derivative functions and students' difficulties. Procedia Social and Behavioral Sciences, 55, 679-684. https:// doi.org/10.1016/j.sbspro.2012.09.551

[11] Taxen, G., \& Naeve, A. (2001). Cyber math: A system for exploring open issues inVR-based education. In The Royal Institute of Technology (Ed.). Sweden.

[12] Goethals, P. L. (2013). The pursuit of higher-order thinking in the mathematics classroom, 15.

[13] Dejarnette, A. F. (2014). Students' conceptions of trigonometric functions and positioning practices during pair work with etoys.

[14] Suzieleez, S. A., \& Sulaiman, T. (2006). Gambaran mental dan perwakilan pelajar lepasan sijil pelajaran malaysia tentang konsep fungsi, 44(December 2014), 45-60. https://doi.org/ 10.11113/jt.v44.391

[15] Bayazit, I., Aksoy, Y., \& Ilhan, O. (2010). Geogebra as a instrucional tool to promote students' operational and structural conception of function. First North American Geogebra conference, 117-122. Retrieved from http://www.geogebra.ir/geogebra/Files/ PDF/6f422611586e49e989db07e51411c508.pdf\#page=121. https://doi.org/10.5948/9781 $\underline{614441113.003}$

[16] Muhammad, F. S. (2011). Masalah pembelajaran matematik dalam tajuk trigonometri II di kalangan pelajar tingkatan 4 .

[17] Darmawan, A. \& Iwan, P. (2011). On the teaching of analyzing the effects of parameter changes on the graph of function. In international seminar and the fourth national conference on mathematics education (pp. 978-979).

[18] Zaleha, A., \& Nurhidayah, O. (2003). Cadangan penggunaan realiti maya (desktop) sebagai bahan bantu mengajar dalam matapelajaran kalkulus II (Graf fungsi/hubungan dalam tiga matra) : Satu kajian terhadap pelajar tahun 2 SPT, Fakulti Pendidikan, Universiti Teknologi Malaysia. https://doi.org/10.11113/jt.v52.136

[19] Mohamad, N. A., Mohd, S. A., Abdul H. A., Mahani, M., \& Noor, A. A. (2014). Meningkatkan kemahiran penaakulan matematik berfokuskan metakognitif dalam kalangan pelajar.

[20] De-Koning, E., Hamers, J. H. M., Sijtsma, K., \& Vermeer, A. (2002). Teaching inductive reasoning in primary education. Developmental Review, 22(2), 211-241. https://doi.org/10. $\underline{1006 / \text { drev.2002.0548 }}$ 
[21] Thompson, T. (2008). Mathematics teachers' interpretation of higher-order thinking in Bloom's taxonomy. International Electronic Journal of Mathematics Education, 3(2), 96109. http://doi.org/10.1126/science.318.5856.1534

[22] Klauer, K. J., \& Phye, G. D. (2008). Inductive reasoning: A training approach. Review of Educational Research, 78(1), 85-123. https://doi.org/10.3102/0034654307313402

[23] Loke, E., \& Ong, M. (2012). Inductive reasoning for learning, 1, 1-12. http://doi.org/10. 1007/s10994-011-5259-2

[24] Abdullah, A. H., Ibrahim, N. H., Surif, J., Ali, M., \& Hamzah, M. H. (2015). Non-routine mathematical problems among in-service and pre-service mathematics teachers. Proceedings of IEEE International Conference on Teaching, Assessment and Learning for Engineering: Learning for the Future Now, TALE 2014, Art. No. 7062620, pp. 18-24. https:// doi.org/10.1109/tale.2014.7062620

[25] Christou, C., \& Papageorgiou, E. (2007). A framework of mathematics inductive reasoning. Learning and Instruction. http://doi.org/10.1016/j.learninstruc.2006.11.009

[26] Manfreda, K. V., Mastnak, A., \& Čadež, T. H. (2011). Primary teacher students' competences in inductive reasoning. In T. Bergqvist (Ed.). Problem solving in mathematics education (pp. 54-68). Umeå university Faculty of Sciences and Technology Umeå Mathematics Education Research Centre, UMERC.

[27] Auzar. (2012). Keberkesanan penggunaan perisian asas membaca. GEMA Online Journal of Language Studies, 12(2), 629-644.

[28] Abdullah, A. H., Rahman, S. N. S. A., \& Hamzah, M. H. (2017). Metacognitive skills of Malaysian students in non-routine mathematical problem solving. Bolema Mathematics Education Bulletin, 31(57), 310-322. https://doi.org/10.1590/1980-4415v31n57a15

[29] Akanmu, I. A. (2011). Geogebra: An effective package for mathematics instruction in Nigeria. School of education, The University of Queensland 4072, 25-32.

[30] Hohenwarter, M. (2006). Dynamic investigation of functions using Geogebra. Proceedings of Dresden International Symposium on Technology and its Integration into Mathematics Education, (x), 5 .

[31] Dikovic, L. (2009). Implementing dynamic mathematics resources with geogebra at the college level. International Journal of Emerging Technologies in Learning, 4(3), 51-54. https://doi.org/10.3991/ijet.v4i3.784

[32] Praveen, S., \& Leong, K. E. (2013). Effectiveness of using Geogebra on students' understanding in learning circles. The Malaysian Online Journal of Educational Technology, 1(4), 1-11.

[33] Dogan, M., \& Icel, R. (2011). The role of dynamic geometry software in the process of learning: Geogebra example about triangles. International Journal of Human Sciences, 8(1), 1441-1458. Retrieved from http://www.time2010.uma.es/Proceedings/Papers/A026 Paper.pdf

[34] Hutkemri, \& Effandi, Z. (2014). Impact of using Geogebra on students' conceptual and procedural knowledge of limit function. Mediterranean Journal of Social Sciences, 5(23), 873-881. https://doi.org/10.5901/mjss.2014.v5n23p873

[35] Suza, H. S. (2014). Reka bentuk Pembelajaran Bagi Meningkatkan Tahap Kefahaman Konsep Pelajar dalam Tajuk Trigonometri Menggunakan Perisian Sumber Terbuka Geogebra.

[36] Syairatul, N. A. (2014). Keberkesanan Pembelajaran Matematik Menggunakan Geogebra Terhadap Pemikiran Geometri Murid. Universiti Teknologi Malaysia.

[37] Chua, Y. P. (2011). Kaedah Penyelidikan (Edisi Kedu). McGraw-Hill SDN BHD.

[38] Brookhart, S. M. (2010). How to assess higher-order thinking skills in your classroom. Alexandria, Virginia USA: ASCD. 
[39] Marzano, R. J., Pickering, D. J., Arredondo, D. E., Blackburn, G. J., Brandt, R. S., Moffett, C. A., \& Whisler, J. S. (1988). Dimension of learning. Teachers manual ( $2^{\text {nd }}$ Ed.).Retrieved from http://files.hbe.com.au/samplepages/197133.pdf

[40] Grice, J. W., \& Iwasaki, M. (2007). A truly multivariate approach to MANOVA. Applied Multivariate Research, 12(3), 199-226. https://doi.org/10.22329/amr.v12i3.660

[41] An, Q., Xu, D., \& Brooks, G. (2013). Type I error rates and power of multiple hypothesis testing procedures in factorial ANOVA. Mlrv.Ua.Edu, 39, 1-16. Retrieved from http:// www.mlrv.ua.edu/2013/vol39_2/An-etal-39_2_proof_1.pdf

[42] Noraini, I. (2013). Penyelidikan dalam pendidikan edisi kedua. Selangor: McGraw-Hill Sdn Bhd.

[43] Jia, Y. B. (2016). Teaching and learning of geometry in primary school using Geogebra, (December)

[44] Marzano, R. J. (1997). Dimensions of learning. Geography.http://doi.org/10.1.4166.0422.7

[45] Fitriana, R. (2011). Pengaruh Pembelajaran Geometri Dengan Pendekatan Induktif. Edumatica, 1, 73-79.

[46] Khor, M. K., \& Ruzlan, M. A. (2016). Penggunaan Geogebra Dalam Pembelajaran Matematik Melalui Pembelajaran Modular. International Seminar on Generating Knowledge through Research, 1(10), 147-154. https://doi.org/10.21070/picecrs.v1i1.591

[47] Zengin, Y., Furkan, H., \& Kutluca, T. (2012). The effect of dynamic mathematics software geogebra on student achievement in teaching of trigonometry. Procedia Social and Behavioral Sciences, 31(2011), 183-187. https://doi.org/10.1016/j.sbspro.2011.12.038

[48] Canadas, M. C., \& Castro, E. (2007). A proposal of categorisation for analysing inductive reasoning. Pna, 1(2), 67-78. http://doi.org/10.1227/01.NEU.0000032542.40308.65

[49] Yüksel, N. S., \& Çildir, S. (2015). The impacts of dynamic geometry software on graphing abilities of prospective physics teachers: Geogebra sample. Eurasian Journal of Physics and Chemistry Education, 7(1), 46-61.

[50] Heit, E. (2000). Properties of inductive reasoning. Psychonomic Bulletin \& Review, 7(4), 569-592. https://doi.org/10.3758/bf03212996

[51] Papageorgiou, E. (2009). Towards a teaching approach for improving mathematics inductive reasoning problem solving. Proceedings of the $33^{\text {rd }}$ Conference of the International Group for the Psychology and Mathematics Education, 4, 313-320.

[52] Diković, L. (2009). Applications geogebra into teaching some topics of mathematics at the college level. Computer Science and Information Systems, 6(2), 191-203. https://doi.org/ $\underline{10.2298 / \mathrm{csis} 0902191 \mathrm{~d}}$

[53] Panorkou, N., Maloney, A., \& Confrey, J. (2014). Developing elementary students' reasoning of geometric transforma tions through dynamic animation. Proceedings of the $3^{\text {rd }}$ International Constructionism Conference, 1-10.

[54] Rohani, A. W., Abdullah, A. H., Mohd, S. A., Mahani, M., \& Noor, A. A. (2016). A case study on visual spatial skills and level of geometric thinking in learning 3D geometry among high achievers, 96(8), 489-499.

[55] Aniţei, M., Dumitru, D., \& Chraif, M. (2014). Inductive reasoning and visual memory. A pilot study. Procedia Social and Behavioral Sciences, 127, 834-839. https://doi.org/10. 1016/j.sbspro.2014.03.364

[56] Nor'ain, M. T., Nurulhuda, A. R., Noor, S. S., Asmayati, Y., Hasimah, A., Mohammad, U. D., \& Mohammad, M. A. K. (2012). Kemahiran penaakulan saintifiK dan stail pengajaran pensyarah: Indikasi awal ke arah peningkatan kualiti pengajaran dan pembelajaran pelajar institusi pengajian tinggi. Jurnal Pendidikan Sains \& Matematik Malaysia, 3(1), 48-59. https://doi.org/10.11113/jt.v29.1094 
[57] Adri, N., Mira, A. A., \& Elfa, R. (2016). Literatur study: The relationship of mathematics problem solving and students' higher, 5, 16-17.

[58] Siti, A. Z., \& Abdullah, A. H. (2017). Kesediaan Guru Menerapkan Kemahiran Berfikir Aras Tinggi ( KBAT ) Dalam Penyelesaian Masalah Matematik, (January).

[59] Royati, A. S., Ahmad, F. M. A., \& Rohani, A. T. (2010). The effects of Geogebra on mathematics achievement: Enlightening coordinate geometry learning. Procedia Social and Behavioral Sciences, 8(5), 686-693. https://doi.org/10.1016/j.sbspro.2010.12.095

[60] Majerek, D. (2014). Application of Geogebra for teaching mathematics. Advances in Science and Technology Research Journal, 8(24), 51-54. http://doi.org/10.12913/22998624 $\underline{1567}$

[61] Reis, Z. A., \& Ozdemir, S. (2010). Using Geogebra as an information technology tool: Parabola teaching. Procedia Social and Behavioral Sciences, 9, 565-572. https://doi.org/10. $\underline{1016 / j . s b s p r o .2010 .12 .198}$

\section{$7 \quad$ Authors}

Noor Suhaily Misrom is from Universiti Teknologi Malaysia, Johor Bahru Malaysia. noorsuhailymisrom@gmail.com

Muhammad Sani Abdurrahman is from Waziri Umaru Federal Polytechnic Birnin Kebbi, Nigeria.

Abdul Halim Abdullah and Sharifah Osman are from Universiti Teknologi Malaysia, Johor Bahru Malaysia.

Mohd Hilmi Hamzah is from Universiti Utara Malaysia, Changlun, Malaysia

Ahmad Fauzan is from Universitas Negeri Padang, Padang, Indonesia

Article submitted 2018-11-09. Resubmitted 2019-09-04. Final acceptance 2019-09-06. Final version published as submitted by the authors 


\section{$8 \quad$ Appendix 1}

\begin{tabular}{|l|l|}
\hline Meeting & 1 \\
\hline Learning objective & To understand and apply the concept of graph function \\
\hline Learning outcome & $\begin{array}{l}\text { At the end of learning you will be able to draw a graph for the function: } \\
\text { linear } y=a x+b \text { where } a \text {, and } b \text { are constant. } \\
\text { quadratic } y=a x^{2}+b x+c \text { where } a, b \text { and } c \text { are constants and } a \neq 0 . \\
\text { cubic } y=a x^{3}+b x^{2}+c x+d \text { where } a, b, c \text { and } d \text { are constants and } a \neq 0 . \\
\text { reciprocal } y=a / x \text { when a is a constant and } a \neq 0 .\end{array}$ \\
\hline
\end{tabular}

\begin{tabular}{|c|c|c|c|}
\hline Group & Group 1 & Group 2 & Group 3 \\
\hline Learning & $\begin{array}{c}\text { Inductive reasoning with Geo- } \\
\text { gebra }\end{array}$ & Inductive Reasoning & Conventional \\
\hline \begin{tabular}{|l} 
Induction \\
Set \\
$(10$ \\
minutes $)$
\end{tabular} & $\begin{array}{l}\text { Students are exposed to situa- } \\
\text { tions or forms of construction } \\
\text { that are part of the form of } \\
\text { graphs of functions to be } \\
\text { learned such as bridges, rollers } \\
\text { and others. } \\
\text { Students also watch video } \\
\text { shows about types of graph } \\
\text { functions in everyday life } \\
\text { through YouTube. } \\
\text { Through student observations } \\
\text { in their environment, students } \\
\text { are asked to list situations or } \\
\text { construction that have a form of } \\
\text { graphs function. } \\
\text { Students are given } 5 \text { minutes to } \\
\text { talk to friends. } \\
\text { A few students are asked to } \\
\text { provide answers and discus- } \\
\text { sions. }\end{array}$ & $\begin{array}{l}\text { Students are exposed to situa- } \\
\text { tions or forms of construction } \\
\text { that are part of the form of } \\
\text { graphs of functions to be } \\
\text { learned such as bridges, rollers } \\
\text { and others. } \\
\text { Through student observations } \\
\text { in their environment, students } \\
\text { are asked to list situations or } \\
\text { construction that have a form } \\
\text { of graphs function. } \\
\text { Students are given } 5 \text { minutes to } \\
\text { talk to friends. } \\
\text { A few students are asked to } \\
\text { provide answers and discus- } \\
\text { sions. }\end{array}$ & $\begin{array}{l}\text { Using textbooks, students are } \\
\text { exposed to several forms of } \\
\text { building construction that are } \\
\text { part of the graph functions. } \\
\text { Through student observations } \\
\text { on the pictures, students are } \\
\text { discussing with the teacher } \\
\text { about the graph of the func- } \\
\text { tion involved. } \\
\text { Students also list and discuss } \\
\text { with teachers about some ex- } \\
\text { amples of situations or con- } \\
\text { struction that have a form of } \\
\text { graph function. }\end{array}$ \\
\hline
\end{tabular}




\begin{tabular}{|c|c|c|c|}
\hline $\begin{array}{l}\text { Learning } \\
\text { Activities } \\
(25 \\
\text { minutes) }\end{array}$ & $\begin{array}{l}\text { Step 1: Inductive Reasoning } \\
\text { Students are exposed to some } \\
\text { examples of linear, quadratic, } \\
\text { cubic and reciprocal graphs by } \\
\text { drawing graphs on graph paper } \\
\text { and creating graphs using Geo- } \\
\text { gebra software. } \\
\text { Using existing knowledge, stu- } \\
\text { dents are required to complete } 1 \\
\text { table by calculating and con- } \\
\text { structing the graph using the } \\
\text { graph paper provided for each } \\
\text { type of graph. } \\
\text { Next, students are required to } \\
\text { complete } 4 \text { tables for each type } \\
\text { of graph by using spreadsheets, } \\
\text { plotting coordinate points and } \\
\text { building graphs using Geogebra } \\
\text { software. } \\
\text { The graphs should be stored in } \\
\text { the specified folder. } \\
\text { Step 2: Inductive Reasoning } \\
\text { Students make an observation } \\
\text { of some examples and look for } \\
\text { patterns and features for linear } \\
\text { graphs, quadratic graphs, cubic } \\
\text { graphs and reciprocal graphs } \\
\text { Based on the graphs, students } \\
\text { are required to observe the pat- } \\
\text { tern of the graphs. } \\
\text { Step 3: Inductive Reasoning } \\
\text { Based on the observation of the } \\
\text { examples, the student draws } \\
\text { general conclusions about the } \\
\text { characteristics of the graphs of } \\
\text { linear, quadratic, cubic and re- } \\
\text { ciprocal functions. } \\
\text { Students also state their under- } \\
\text { standing of the differences in } \\
\text { characteristics of linear, quad- } \\
\text { ratic, cubic and reciprocal } \\
\text { graphs. } \\
\text { Then students are asked to draw } \\
\text { conclusions on the characteris- } \\
\text { tics of the graphs. } \\
\text { For each type of function } \\
\text { graph, the student is required to } \\
\text { make a comparison between the } \\
\text { characteristics of the other } \\
\text { function graphs. }\end{array}$ & $\begin{array}{l}\text { Step 1: Inductive Reasoning } \\
\text { Students are exposed with } \\
\text { some specific examples of lin- } \\
\text { ear, quadratic, cubic and re- } \\
\text { ciprocal graphs by drawing } \\
\text { graphs on graph paper. } \\
\text { By using existing knowledge, } \\
\text { students are required to com- } \\
\text { plete } 16 \text { tables and plot } 16 \\
\text { graphs on the provided graph } \\
\text { paper. } \\
4 \text { linear graphs } \\
4 \text { quadratic graphs } \\
4 \text { cubic cubes } \\
4 \text { reciprocal graphs } \\
\\
\text { Step 2: Inductive Reasoning } \\
\text { Students make an observation } \\
\text { of some examples and look for } \\
\text { patterns and features for linear } \\
\text { graphs, quadratic graphs, cu- } \\
\text { bic graphs and reciprocal } \\
\text { graphs } \\
\text { Based on the graphs, students } \\
\text { are required to observe the pat- } \\
\text { tern of the graphs. } \\
\text { Step 3: Inductive Reasoning } \\
\text { Based on the observation of the } \\
\text { examples, the student draws } \\
\text { general conclusions about the } \\
\text { characteristics of the graphs of } \\
\text { linear, quadratic, cubic and re- } \\
\text { ciprocal functions. } \\
\text { Students also state their under- } \\
\text { standing of the differences in } \\
\text { characteristics of linear, quad- } \\
\text { ratic, cubic and reciprocal } \\
\text { graphs. } \\
\text { Students are then asked to draw } \\
\text { conclusions on the characteris- } \\
\text { tics of linear, quadratic, cubic } \\
\text { and reciprocal graphs. } \\
\text { For each type of function } \\
\text { graph, the student is required to } \\
\text { make a comparison between } \\
\text { the characteristics of the other } \\
\text { function graphs. }\end{array}$ & \begin{tabular}{|l|} 
Students are exposed with in- \\
formation available from \\
graphs such as graphs, $x / y$ \\
intercepts, maximum / mini- \\
mum points and symmetrical \\
axes. \\
Students are also exposed to \\
the general form and the \\
highest power x for each type \\
of function. \\
Using the examples in the \\
textbook, students are ex- \\
posed about the way to draw \\
linear, quadratic, cubic and \\
reciprocal graphs correctly \\
Students are exposed by sev- \\
eral examples of linear, quad- \\
ratic, cubic and reciprocal \\
graphs and some students are \\
asked to draw the graph in \\
front of the class using the \\
graph board. \\
From these examples, stu- \\
dents review graphic features \\
based on the information that \\
the teacher reveals at the be- \\
ginning of the lesson.
\end{tabular} \\
\hline
\end{tabular}




\begin{tabular}{|c|c|c|c|}
\hline \begin{tabular}{|l} 
Exercise \\
Activities \\
$(20$ \\
minutes $)$
\end{tabular} & $\begin{array}{l}\text { Step 4: Inductive Reasoning } \\
\text { Students review the general } \\
\text { conclusions made by complet- } \\
\text { ing the exercises provided. If } \\
\text { the conclusions are incorrect, } \\
\text { then students need to recheck } \\
\text { and rebuild new general con- } \\
\text { clusions. } \\
\text { Based on these examples, stu- } \\
\text { dents are required to use that } \\
\text { knowledge to solve some of the } \\
\text { questions as a practice and } \\
\text { check the general conclusions } \\
\text { made for each type of graph. } \\
\text { Students exchange worksheets } \\
\text { with friends for review pur- } \\
\text { poses. } \\
\text { Discussions between students } \\
\text { and teachers are conducted. } \\
\text { Teachers evaluate students' in- } \\
\text { ductive reasoning from activi- } \\
\text { ties carried out through assess- } \\
\text { ment rubrics. }\end{array}$ & \begin{tabular}{|l|} 
Step 4: Inductive Reasoning \\
Students review the general \\
conclusions made by complet- \\
ing the exercises provided. If \\
the conclusions are incorrect, \\
then students need to recheck \\
and rebuild new general con- \\
clusions. \\
Based on these examples, stu- \\
dents are required to use that \\
knowledge to solve some of the \\
questions as a practice and \\
check the general conclusions \\
made for each type of graph. \\
Students exchange worksheets \\
with friends for review pur- \\
poses. \\
Discussions between students \\
and teachers are conducted. \\
Teachers evaluate students' in- \\
ductive reasoning from activi- \\
ties carried out through assess- \\
ment rubrics.
\end{tabular} & $\begin{array}{l}\text { Based on these examples, } \\
\text { students are required to com- } \\
\text { plete the exercises in the } \\
\text { textbook } \\
\text { Teacher guides students to } \\
\text { solve the questions. }\end{array}$ \\
\hline \begin{tabular}{|l} 
Reflection \\
and Closing \\
$(5$ minutes $)$
\end{tabular} & $\begin{array}{l}\text { tudents revise general conclu- } \\
\text { sions about the characteristics } \\
\text { of the graph and the differences } \\
\text { in feature of the function graph. } \\
\text { The student's work should be } \\
\text { sent via e-mail for review and } \\
\text { comment given depending on } \\
\text { the student's work. }\end{array}$ & $\begin{array}{l}\text { Students revise general conclu- } \\
\text { sions about the characteristics } \\
\text { of the graph and the differences } \\
\text { in feature of the function } \\
\text { graph. } \\
\text { Student work is collected for } \\
\text { review and comments are } \\
\text { given depending on student } \\
\text { work. }\end{array}$ & $\begin{array}{l}\text { Students revise the character- } \\
\text { istics of the graphs learned. } \\
\text { Student work is collected for } \\
\text { review. }\end{array}$ \\
\hline
\end{tabular}

